\title{
Developing Computer Program as a Learning Resource on Gas Law Topics for High School Students
}

\section{Elisabeth Pratidhina}

Department of Physics Education, Widya Mandala Catholic University, Surabaya, Indonesia, elisa.founda@ukwms.ac.id

\section{Pujianto}

Department of Physics Education, Yogyakarta State University, Yogyakarta, Indonesia

\section{Yosaphat Sumardi}

Department of Physics Education, Yogyakarta State University, Yogyakarta, Indonesia

The research aims to: (1) produce a computer program as a learning resource on gas law topics; (2) determine the appropriateness and quality of the computer program; and (3) describe the effectiveness of the computer program to help students in learning the concept of gas law. We employed 4D (define, design, develop, disseminate) models in this research. The computer program is validated by physics expert, learning media expert, and physics teachers. The appropriateness and quality of the computer program were analyzed descriptively. The field testing involved a small group consists of 4 students and a larger group consists of 61 students. The effectiveness of the computer program in improving students' learning achievement was investigated through one group pretest and posttest design. The results of this study showed that the computer program is feasible for high school physics learning. Based on the assessment by physics experts, learning media experts and high school physics teachers, the quality of computer program can be categorized as very good. Normalized gains from the conducted pretest and posttest to small and larger group are found as 0.68 and 0.55 , respectively. It indicates that there is medium improvement of students' learning achievement after using the computer program as a learning resource.

Keywords: computer-based learning resource, gas law, high school physics, learning resource, developing computer program

\section{INTRODUCTION}

In some occasions carrying experiment or practical work in science course is difficult. It is due to complexity of instruments, limited time that teachers have, difficulty of class 
management during the experiment etc. On the other hand, practical work is important in science course (Barrie et al., 2015). High-quality laboratory develops many skills such as data processing, and analysis, observation, interpretation, problem solving, critical thinking skills, scientific reasoning, communication, presentation, ethical and professional behavior, and teamwork (Schmid \& Read, 2010). Laboratory work also has goas such as to encourage accurate observation and description, to make scientific phenomena more real, to enhance understanding of scientific ideas, to arouse and maintain interest, to promote a scientific method of thought (Hofstein, 2017). Although in some cases, carrying real experiment activity in the classroom is difficult, adapting experiment activity in the computer program is possible (Rutten, Van Joolingen, \& Van Der Veen, 2012; Supurwoko et al., 2017).

The impressive development of computer technology gives rise to the use of computer in learning process (De Witte, Haelermans, \& Rogge, 2015; Kleij, Feskens, \& Eggen, 2015; Merchant, Goetz, Cifuentes, Keeney-Kennicutt, \& Davis, 2014). Computer assisted learning in science education have also been studied widely (Rutten, Veen, \& Joolingen, 2015; Smetana \& Bell, 2012; Tsai \& Chou, 2002). Some researches indicate that students' achievement increases with the use of computer in science education (Erdoğan \& Dede, 2015; Powell, Aeby, \& Carpenter-Aeby, 2003). Moreover, the use of computer in learning science may support abstract reasoning abilities (Chang, Chen, Lin, \& Sung, 2008).

Enormous number of physics education software arises, such as: tools for the acquisition and manipulation of data, multimedia software, micro worlds and simulation, modeling tools, telematics and internet tools. Simulations are programs that contain models of physical process and display visualization of them. Simulations can encourage students to explore the physical system, set physical parameter, manipulate physical quantity and observe the result of the manipulation. Simulations provide students with opportunity to develop their understanding about the physical phenomena and laws through the hypothesis making and idea testing. Simulations also allow students to manipulate parameters and investigate the phenomena that would not be possible to experience in a classroom or even in laboratory (Rutten et al., 2012).

Experiment to investigate gas law is not easy to be carried in the classroom. It is still possible to be conducted through lab activities. However, not every school has apparatus to conduct this experiment. Moreover, gas law is related to the concept of kinetic theory of gas. In kinetic theory of gas, there are many concepts about microscopic things which are difficult to be observed directly (Niaz, 2000). In this case, computer-based media can provide experimental simulation and microscopic visualization of gas which may become an alternative way to do virtual experiment. Computer based media may help students in understanding the concepts of gas law and theory of kinetic gas.

In addition, sometimes students need to do individual learning activity outside the class. For some students, the regular class time may be not enough to deeply understand the physical concepts. Some students probably miss some concepts in the class so they need self-recitation. Therefore, students also need a learning resource that can accommodate them to do individual learning activity by themselves. 
In Indonesia, computer has been integrated in science learning. Researchers and science teachers have tried to use computer assisted learning in science class. Some of them used the existed program such as PhET (Saputra, Nur, \& Purnomo, 2016; Wartono \& Batlolona, 2018), some of them have tried to develop their own program (Gunawan, Harjono, \& Sutrio, 2015; Wulandari, Dewi, \& Akhlis, 2013). Related to the topics of gas law, there is computer program developed such as virtual reality modelling language (VRML) in kinetic theory of gas (Wartono \& Batlolona, 2018). The computer program has been validated and tested to students, however the field testing did not evaluate the impact of those programs on learning process. Moreover, the programs are not specifically designed for individual learning purpose on gas law topics.

This study aims to develop a computer program as a learning resource on gas law topics that can be used as both a learning media support in class and individual learning resource outside the class. Even though there are existing learning resources to support students in learning gas law in Indonesia, so far, we could not find comprehensive learning resource that provide complete features which are appropriate for individual learning purpose. Our developed computer programs are accompanied by simulation, concepts explanation and application with video and animation, problem exercise, and quiz. Other than that, the computer program was developed in bilingual i.e. Indonesian and English to support bilingual learning for students who need it. To face the global era, promoting bilingual study in Indonesia is also necessary, but the number of learning resources to support it is still limited. In this research, the appropriateness and quality of the computer program were determined. The effectiveness of the computer program to help students in learning the concept of gas law was also investigated through field testing.

\section{METHOD}

\section{Research Design}

In this study, we adapted research and development method within 4D models (Thiagarajan, Sammel, \& Melvyn, 1974). The 4D model consists of 4 main stages, i.e. define, design, develop, and disseminate. In the define stage, we did need analysis, task and concept analysis. The need analysis is done by observation in class and interview with several physics teachers. The task and concept analysis were done by matching the material with the physics curricula in Indonesia. Based on some analysis in the define stage, we designed the computer program with Adobe Flash CS4 software (Adobe, 2009). The design stage results the prototype of computer program that is ready for develop stage through several evaluation and testing.

The develop stage is initiated by experts' appraisal. An expert in physics (thermodynamic and statistical mechanics) and an expert in computer-based learning media evaluated the computer program. Evaluation was also done by three high school physics teachers. The evaluation result from experts and high school physics teachers became consideration for computer program revision.

After experts' appraisal and evaluation from physics teachers, the computer media was tested by high school students. The preliminary testing was done to a smaller group 
consisting of 4 students. The students' response in the preliminary testing was used as a consideration for the improvement of computer program. After several revisions, the computer program was tested to a larger group consist of 64 high school students. We used one group pretest and posttest design in the field testing. Finally, from the field testing in the larger group of students, students gave response to the computer program that they used. The responses were used as consideration for the final revision. The final version of computer program was distributed in some schools.

\section{Research Instrument}

The quality of the computer program was determined through experts' appraisal, teachers' evaluation and students' response. The instruments used for gathering experts' appraisal, teachers' evaluation and students' response were questionnaires. The questionnaire was developed using Likert scale (1-5). The questionnaires for evaluation by material experts cover three aspects, i.e. instructional, context (material), and languages. The questionnaires for evaluation by learning media experts cover two aspects, i.e. layout and accessibility. The questionnaire for evaluation by physics teachers cover four aspects, i.e. instructional, context/material, language, accessibility, and layout.

The students' responses were gathered through "yes" or "no" checklist. The checklist contains several statements which actually gathered the students' response about fitness for individual learning purpose, usefulness, layout, language, and accessibility.

The effectiveness of the computer program to help students in learning the concept of gas law was determined by comparing the pretest and posttest result. The students were given a pretest before they used the computer program as a learning resource. After they studied using the computer program, they were given posttest. The pretest and posttest consist of 15 items to assess the students' conceptual understanding on gas law topics. The items were contextually and constructively validated by our colleagues who are expert in thermodynamics and in physics education.

\section{Technique of Data Analysis}

In this study, we used descriptive technique in the data analysis. The evaluation scores of computer program quality given by the experts and physics teachers through questionnaires were averaged. The average scores of each aspect were classified into appropriateness level based on the criteria in Table 1. Eko Putro Widoyoko makes a classification with comparison to the ideal average score $\left(X_{i}\right)$ and the ideal standard deviation score $(S D i)$ as basis. The qualification level is divided into five categories with criteria as in Table 1 (Eko Putro Widoyoko, 2016). 
Table 1

Conversion of Actual Average Score to Qualitative Criteria (5 Scale)

\begin{tabular}{llll}
\hline No & Score & Score Interval & Criteria \\
\hline 1 & $\bar{X}>\bar{X}_{i}+1.8 S D i$ & $\bar{X}>4.2$ & Very Good \\
2 & $\bar{X}_{i}+0.6 S D i<\bar{X} \leq \bar{X}_{i}+1.8 S D i$ & $3.4<\bar{X} \leq 4.2$ & Good \\
3 & $\bar{X}_{i}-0.6 S D i<\bar{X} \leq \bar{X}_{i}+0.6 S D i$ & $2.6<\bar{X} \leq 3.4$ & Fair \\
4 & $\bar{X}_{i}-1.8 S D i<\bar{X} \leq \bar{X}_{i}-0.6 S D i$ & $1.8<\bar{X} \leq 2.6$ & Poor \\
5 & $\bar{X} \leq \bar{X}_{i}-1.8 S D i$ & $\bar{X} \leq 1.8$ & Very Poor \\
\hline
\end{tabular}

$\bar{X}$ : average score of each aspect

$\bar{X}_{i}: 1 / 2$ (maximum ideal score + minimum ideal score)

$S D i=1 / 6$ (maximum ideal score - minimum ideal score)

The students' response to computer program was gathered through "yes" or "no" checklist (dichotomous scale). The "yes" or "no" answer were converted into numerical data; the conversion is given in Table 2. After conversion, the numerical data were averaged and interpreted according the criteria in Table 3.

Table 2

Conversion of Students' Answer into Numerical Data

\begin{tabular}{ccc}
\hline Answer & Score for Positive Statement & $\begin{array}{c}\text { Score for Negative } \\
\text { Statement }\end{array}$ \\
\hline Yes & 1 & 0 \\
No & 0 & 1 \\
\hline
\end{tabular}

Table 3

Conversion of Actual Average Score to Qualitative Criteria (dichotomous scale)

\begin{tabular}{llll}
\hline No & Score & Score Interval & Criteria \\
\hline 1 & $\bar{X}>\bar{X}_{i}+1.8 S D i$ & $\bar{X}>4.2$ & Very Good \\
2 & $\bar{X}_{i}+0.6 S D i<\bar{X} \leq \bar{X}_{i}+1.8 S D i$ & $3.4<\bar{X} \leq 4.2$ & Good \\
3 & $\bar{X}_{i}-0.6 S D i<\bar{X} \leq \bar{X}_{i}+0.6 S D i$ & $2.6<\bar{X} \leq 3.4$ & Fair \\
4 & $\bar{X}_{i}-1.8 S D i<\bar{X} \leq \bar{X}_{i}-0.6 S D i$ & $1.8<\bar{X} \leq 2.6$ & Poor \\
5 & $\bar{X} \leq \bar{X}_{i}-1.8 S D i$ & $\bar{X} \leq 1.8$ & Very Poor \\
\hline
\end{tabular}

$\bar{X}$ : average score of each aspect

The effectiveness of the computer program to help students in learning the concept of gas law were investigated. Pre-test and post-test were conducted before and after students used the learning resource for individual learning activity. We used one group pre-test and post-test design in this research and then analyze the normalized gain score using equation (1). In formula (1), \% post-test score denotes the score of post-test in percent, \%pre-test score denotes the score of pre-test in percent, while $g$ is the 
normalized gain score (Hake, 1998). The gain score indicates how significant the improvement of the students' conceptual understanding is. The criteria are given in Table 4.

$$
g=\frac{96 p o s t t e s t \text { score-9hpretest score }}{100-96 p r e t e s t \text { score }}
$$

Table 4

The Criteria of Gain Score $(g)$ (Hake, 1998)

\begin{tabular}{ll}
\hline$g$ & Criteria \\
\hline $\mathrm{g}>0,7$ & High \\
$0,3<\mathrm{g} \leq 0,7$ & Medium \\
$\mathrm{g} \leq 0,3$ & Low \\
\hline
\end{tabular}

\section{FINDINGS}

\section{The Feature of the Learning Resource}

The learning resource consists of some features such as material, simulation of experiments, exercise, quiz, and scientists' biography. The features contained in this learning resource are presented in the home page of the computer program, as shown in Figure 1. Material contains introduction to physical concepts, concepts' explanation, basic mathematical derivation, and some examples of related physical phenomena. The material is accompanied by videos and animation.

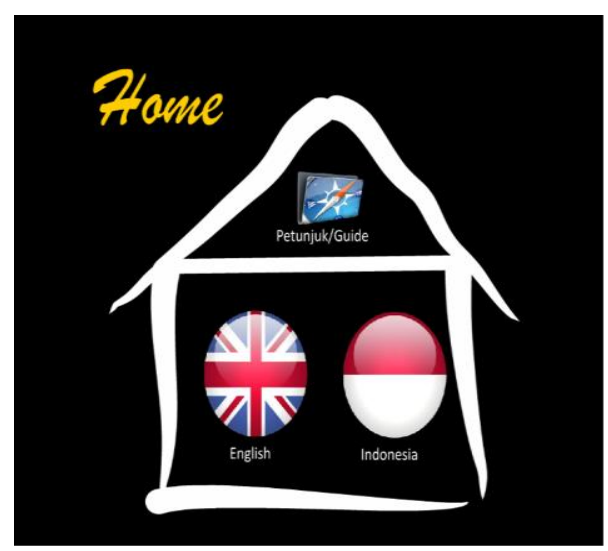

(a)

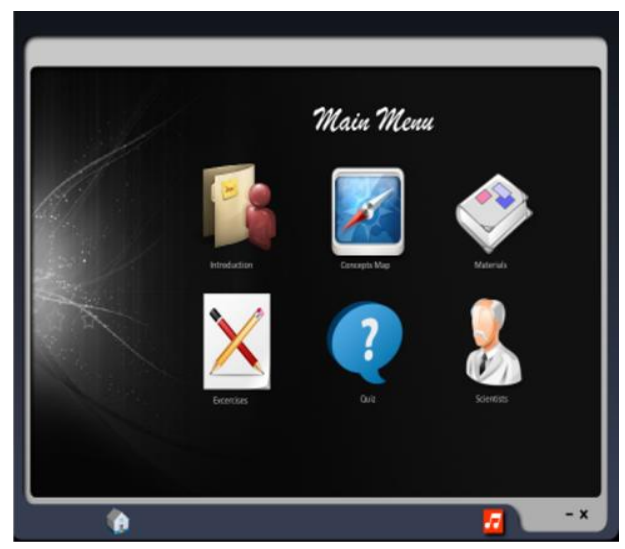

(b)

Figure 1

The layout of (a) home page and (b) main menu. This learning resource is available in both English and Indonesian.

This learning resource also includes simulation of ideal gas experiments. As the experiments are not always easy to be carried out in the physics class, we developed some simulations that may become an alternative to substitute hands-on experiments. 
Students are guided to find the relationship between pressure and temperature $(P-T)$, volume and temperature $(V-T)$, and pressure and volume $(P-V)$ in ideal gas system through the simulation. Students have to present their result in a graph form and interpret the result. The activity in the simulation can be used in both ordinary class and individual learning activity outside ordinary class. In an ordinary traditional class, teacher will be the facilitator who guides students to gather data, analyze, and present the result. However, the learning resource still can be used in individual learning activity where there is no instructor because the learning resource provides detail guides from taking the data to interpreting the data (see Figure 2).

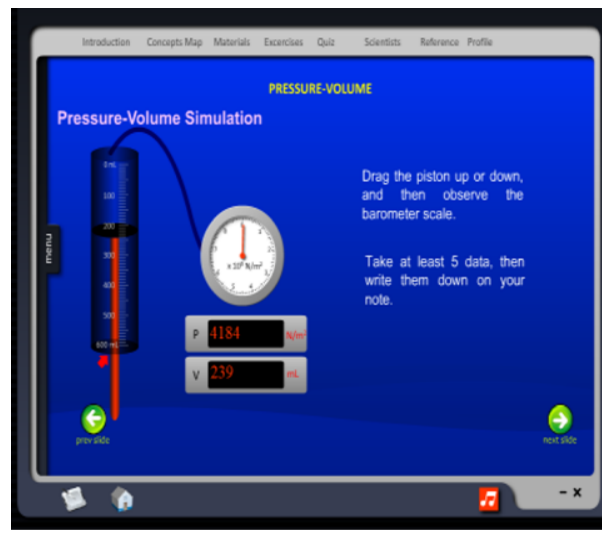

(a)

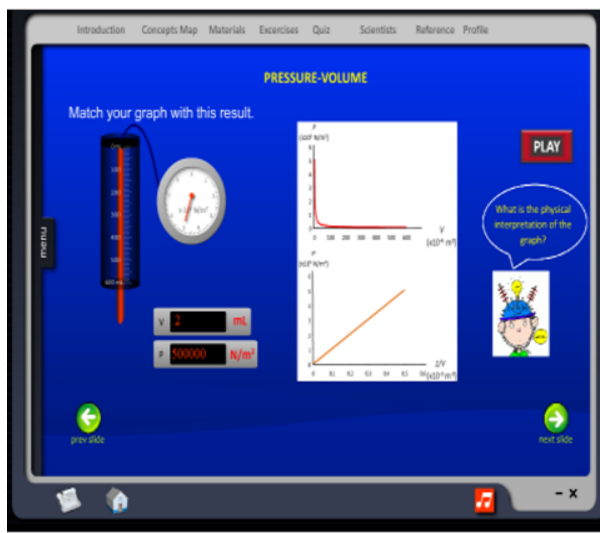

(c)

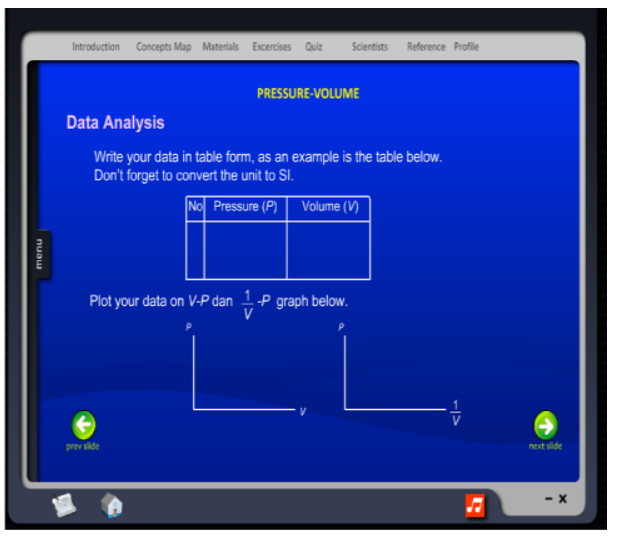

(b)

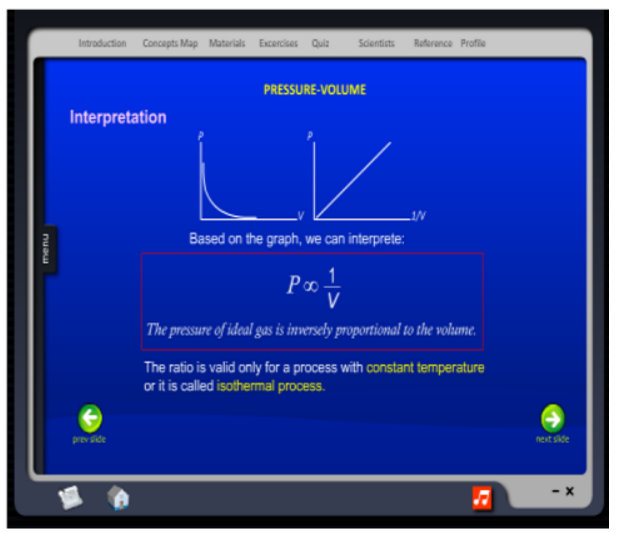

(d)

Figure 2

Simulation of $P-V$ relationship. The simulation contains some activities such as (a) data collecting, (b) data analysis, (c) confirmation of result through automatic simulation, and (d) interpretation of result. 
Besides $P-V$ - $T$ relationship in ideal gas, simulation of root-mean-squared (rms) speed of gas molecules is also provided. The simulation shows the relation between temperature, relative mass, and rms speed of gas molecules, the simulation is adopted from PhET (PhET, 2018). The relationship between some quantities in kinetic theory of gas is derived mathematically with a simple assumption. This explanation aims to give the students a comprehensive understanding from theoretical point of view and experimental result.

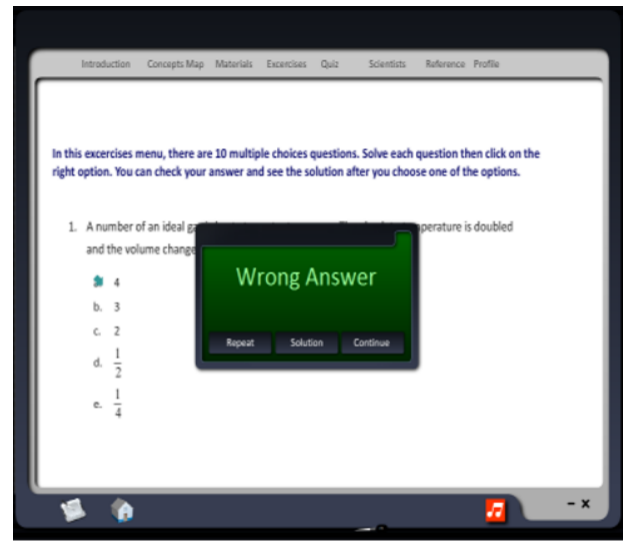

(a)

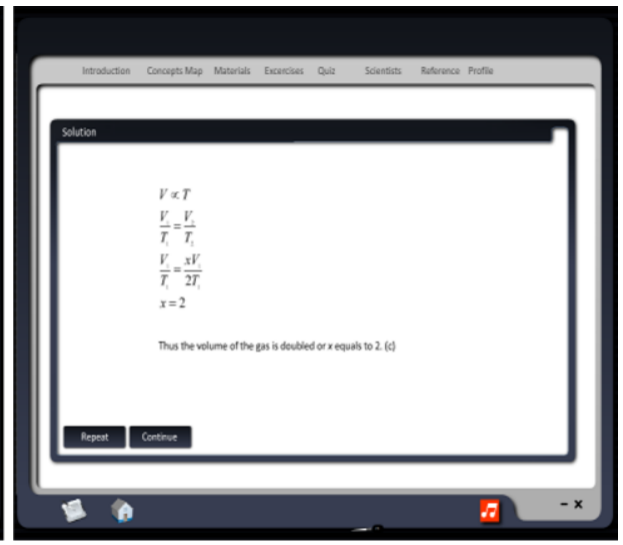

(b)

Figure 3

The layout of Exercises Menu. (a) Problem given in the Exercises. (b) The problem solutions.

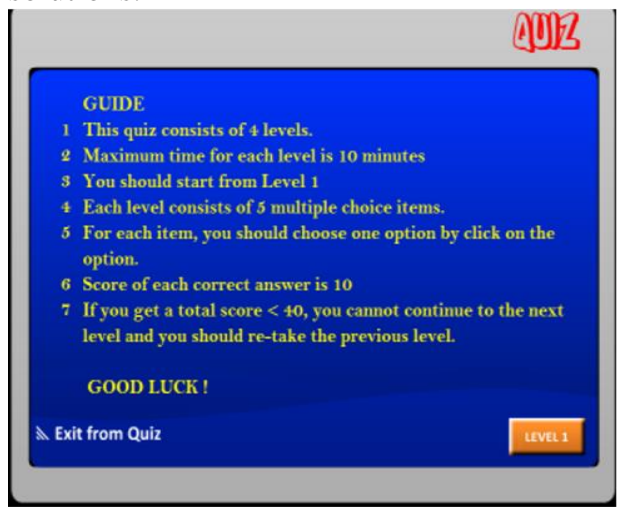

(a)

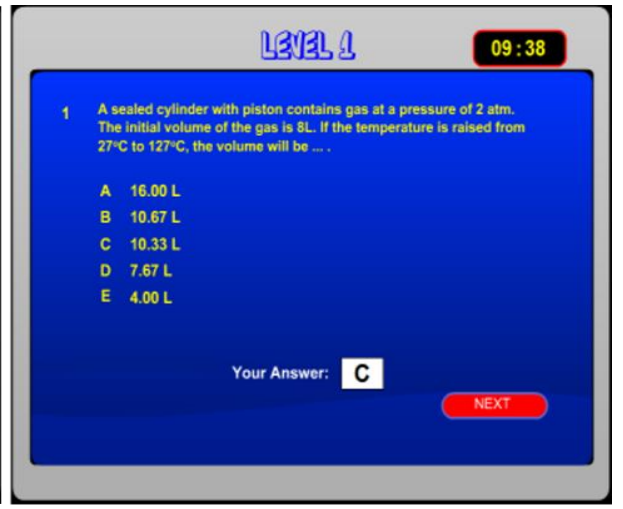

(b)

Figure 4

The layout of Quiz Menu. (a) The Guidelines. (b) Problem displayed in Quiz, there are 5 randomly displayed questions in each level and students must answer them within 10 minutes. 
Exercise allows students to apply some concepts that have been studied in the material to solve some problems. In the exercise, the solutions of each problem are provided; one of examples is given in Figure 3. Move up to the next level, students can do Quiz, as shown in Figure 4, to evaluate their study by themselves. The Quiz is constructed from 4 levels with different difficulties of problems. Students have to pass $\geq 80 \%$ score if they want to go the next level. The questions of each level are always randomly changed if students restart the quiz.

Figure 5 shows the last feature of this learning resource, scientists' biography. The biography of some physicists who worked on the experimental and theoretical studies related to ideal gas and kinetic theory of gas is presented. This feature aims to motivate students for further studies.

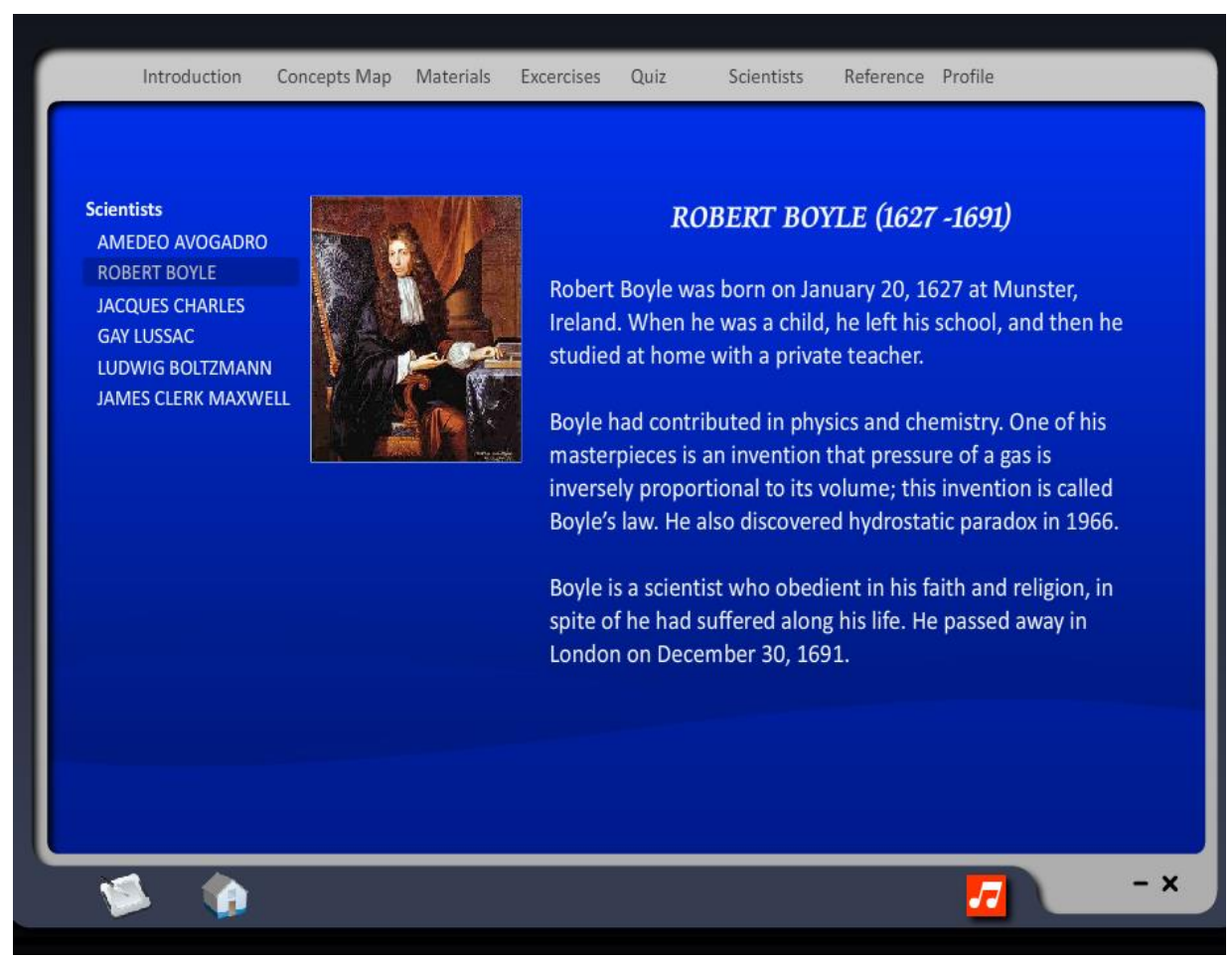

Figure 5

Short biography of scientist who worked on gas law and theory kinetic gas is also included.

\section{Developmental Testing of the Learning Resource}

The learning resource has been validated through expert appraisal and tested to senior high school students. We also asked some teachers to use this learning resource and fill a questionnaire to evaluate the computer program. Overall, teachers agreed that this 
computer program is potentially can be used by students as their individual learning resources on ideal gas and theory of kinetic gas material. The learning resource was revised based on some advices from experts and physics teachers before being directly tested to students.

We did initial field testing to a small group consists of 4 students. To measure students' initial knowledge of gas law, a pre-test was given to students. After that, students learnt the material by themselves using the learning resource that we have developed. A posttest was given to them to measure their final understanding on the material after they used the learning resource. Using equation (1), the results of pre- and post-test were analyzed to yield the normalized gain-score. The average gain score from the first field testing was 0.68 , which is categorized as medium gain (Hake, 1998). At the end of the session they also filled the checklist about their opinion of the quality and usability of the learning resource.

We received some advices from this initial field testing and thus we did a minor revision on the learning resource. We did the second field testing to a bigger group of students. On this field testing, there were 61 students from two schools. Similarly, we conducted pre- and post-test to students before and after they used the learning resource to study the material by themselves. The average gain score from the second field testing was found as 0.55 , which is categorized as medium gain (Hake, 1998). Table 3 shows the average of pre- and post-test score and gain score.

Table 3

The Comparison of Pre- and Post-Test Score and the Gain

\begin{tabular}{lllll}
\hline Group & $\begin{array}{l}\text { Average pre-test } \\
\text { score } \\
\text { (out of 100) }\end{array}$ & $\begin{array}{l}\text { Average post-test } \\
\text { score } \\
\text { (out of 100) }\end{array}$ & $\begin{array}{l}\text { Average gain } \\
\text { score }\left(\mathrm{g}_{\mathrm{av}}\right)\end{array}$ & Criteria \\
\hline $\begin{array}{l}\text { Smaller group } \\
\text { (4 students) }\end{array}$ & 38.33 & 80.00 & 0.68 & Medium \\
$\begin{array}{l}\text { Bigger group } \\
\text { (61 students) }\end{array}$ & 41.99 & 73.87 & 0.55 & Medium \\
*Average gain score is calculated by averaging each individual gain scores in the group. \\
\hline
\end{tabular}

After each field testing, we gave students some checklist to know their opinions about the quality and usability of the learning resource. The final results are summarized in Table 4. Overall, most of students from the initial field testing (smaller group) and second field testing (bigger group) agreed that the fitness of learning resource for individual learning activity, the usefulness of the learning resource to learn ideal gas and theory kinetic gas, layout quality, language quality, and accessibility of the learning resource are very good. 
Table 4

Students' Response on Checklist about the Quality and Usability of the Learning Resource

\begin{tabular}{|c|c|c|c|c|}
\hline \multirow[b]{2}{*}{ Aspects } & \multicolumn{2}{|c|}{ Smaller Group } & \multicolumn{2}{|c|}{ Bigger Group } \\
\hline & $\begin{array}{l}\text { Average } \\
\text { Score }\end{array}$ & Criteria & $\begin{array}{l}\text { Average } \\
\text { Score }\end{array}$ & Criteria \\
\hline $\begin{array}{l}\text { The fitness for individual } \\
\text { learning purpose }\end{array}$ & 0.94 & Very Good & 0.86 & Very Good \\
\hline $\begin{array}{l}\text { The usefulness of to learn ideal } \\
\text { gas and theory kinetic gas }\end{array}$ & 0.94 & Very Good & 0.90 & Very Good \\
\hline Layout quality & 0.81 & Very Good & 0.88 & Very Good \\
\hline Language quality & 0.94 & Very Good & 0.85 & Very Good \\
\hline Accessibility & 0.94 & Very Good & 0.86 & Very Good \\
\hline
\end{tabular}

We found there is significant improvement of students' cognitive achievement after students learned individually using the developed computer program. Both preliminary field testing and main field testing showed medium gain score of pre- and post-test result. Our developed computer program mainly consists of simulation of experiment and concept explanation which accompanied with video and animation to engage students and show the example of concept application in daily life. Our finding is consistent with previous studies which showed that physics simulation based learning give good impact on learning results (Jimoyiannis \& Komis, 2001; Srisawasdi \& Panjaburee, 2015; Syaifulloh \& Jatmiko, 2014).

Simulation of experiment and concept animation helps students to learn abstract concept such as kinetic theory of gas which included in the gas law topics. Other than that, guided simulation of experiments developed in our program has the potential to improve students' ability on data processing and graph interpretation. If we looked at the details, we found that in the post-test, the number of students who gave correct answer about problems related to data processing and graph interpretation is higher than in the pretest.

In this study we have investigated the impact of using the developed computer program in the students' learning results in gas law topics. However, this study is limited to the investigation on cognitive learning result only. We believe that more comprehensive investigation on other domains such as affective domain is also required.

\section{CONCLUSION}

A study has been conducted to develop computer based individual learning resources on the material of gas law. The learning resource has been tested to groups of students. Based on the gain score analysis, the learning resource is potentially can be used to improve students' understanding on gas law effectively. Students' response on the usability and quality of the learning resource in overall can be categorized as very good. Still, the study still has limitation since we only evaluated the learning result on cognitive domain. For further study, comprehensive investigation on other domains such as affective domain is also required. 


\section{REFERENCES}

Adobe. (2009). Adobe Flash CS4 Professional update. Retrieved from https://www.adobe.com/support/flash/downloads.html\#flashCS4

Barrie, S. C., Bucat, R. B., Buntine, M. A., Burke, K., Crisp, G. T., George, A. V, ... Yeung, A. (2015). Development, evaluation and use of a student experience survey in undergraduate science laboratories: The advancing science by enhancing learning in the laboratory student laboratory learning experience survey. Internatioal Journal of Science Education, 37(11), 1795-1814. https://doi.org/10.1080/09500693.2015.1052585

Chang, K. E., Chen, Y. L., Lin, H. Y., \& Sung, Y. T. (2008). Effects of learning support in simulation-based physics learning. Computers and Education, 51(4), 1486-1498. https://doi.org/10.1016/j.compedu.2008.01.007

De Witte, K., Haelermans, C., \& Rogge, N. (2015). The effectiveness of a computerassisted math learning program. Journal of Computer Assisted Learning, 31(4), 314329. https://doi.org/10.1111/jcal.12090

Eko Putro Widoyoko. (2016). Evaluasi Program Pembelajaran: Panduan Praktis Bagi Pendidik dan Calon Pendidik. (Saifudin Zhri Qudsy, Ed.) (8th ed.). Yogyakarta: Pustaka Pelajar.

Erdoğan, Y., \& Dede, D. (2015). Computer assisted project-based instruction: The effects on science achievement, computer achievement and portfolio assessment. International Journal of Instruction, 8(2), 177-188. https://doi.org/10.12973/iji.2015.8214a

Gunawan, Harjono, A., \& Sutrio. (2015). Multimedia interaktif dalam pembelajaran konsep listrik bagi calon guru. Jurnal Pendidikan Fisika Dan Teknologi, I(1), 9-14. https://doi.org/10.29303/jpft.v1i1.230

Hake, R. R. (1998). Interactive-engagement versus traditional methods: A six-thousandstudent survey of mechanics test data for introductory physics courses. American Journal of Physics, 66(1), 64-74. https://doi.org/10.1119/1.18809

Hofstein. (2017). The role of laboratory in science teaching and learning. In Science Education. New Directions in Mathematics and Science Education. Rotterdam: SensePublishers.

Jimoyiannis, A., \& Komis, V. (2001). Computer simulations in physics teaching and learning : a case study on students' understanding of trajectory motion. Computers \& Education, 36, 183-204. https://doi.org/10.1016/S0360-1315(00)00059-2

Kleij, F. M. Van Der, Feskens, R. C. W., \& Eggen, T. J. H. M. (2015). Effects of feedback in a computer-based learning environment on students' learning outcomes: A meta-analysis. Review of Educational Research, 85(4), 1-37. https://doi.org/10.3102/0034654314564881 
Merchant, Z., Goetz, E. T., Cifuentes, L., Keeney-Kennicutt, W., \& Davis, T. J. (2014). Effectiveness of virtual reality-based instruction on students' learning outcomes in K-12 and higher education: A meta-analysis. Computers and Education, 70, 29-40. https://doi.org/10.1016/j.compedu.2013.07.033

Niaz, M. (2000). A rational reconstruction of the kinetic molecular theory of gases based on history and philosophy of science and its implications for chemistry textbooks. Instructional Science, 28(1), 23-50. https://doi.org/10.1023/A:1003429101358

PhET. (2018). Gas Properties. Retrieved from https://phet.colorado.edu/en/simulation/gas-properties

Powell, J. V., Aeby, V. G., \& Carpenter-Aeby, T. (2003). A comparison of student outcomes with and without teacher facilitated computer-based instruction. Computers and Education, 40(2), 183-191. https://doi.org/10.1016/S0360-1315(02)00120-3

Rutten, N., Van Joolingen, W. R., \& Van Der Veen, J. T. (2012). The learning effects of computer simulations in science education. Computers and Education, 58(1), 136-153. https://doi.org/10.1016/j.compedu.2011.07.017

Rutten, N., Veen, J. T. Van Der, \& Joolingen, W. R. Van. (2015). Inquiry-based wholeclass teaching with computer simulations in physics. International Journal of Science Education, 37(8), 1225-1245. https://doi.org/10.1080/09500693.2015.1029033

Saputra, T. B. R. E., Nur, M., \& Purnomo, T. (2016). Desain riset perangkat pembelajaran menggunakan media kit listrik yang dilengkapi PhET berbasis inkuiri untuk melatihkan keterampilan proses sains. Unnes Science Education Journal, 5(3), 1331-1342. https://doi.org/10.15294/usej.v5i3.13162

Schmid, S., \& Read, J. R. (2010). Teaching and learning in laboratory setting. In R. H. Cantwell \& J. J. Scevak (Eds.), An Academic Life: A Handbook for New Academics. Victoria: ACER Press.

Smetana, L. K., \& Bell, R. L. (2012). Computer simulations to support science instruction and learning: A critical review of the literature. International Journal of Science Education, 34(9), 1337-1370. https://doi.org/10.1080/09500693.2011.605182

Srisawasdi, N., \& Panjaburee, P. (2015). Exploring effectiveness of simulation-based inquiry learning in science with integration of formative assessment. Journal of Computers in Education, 2(3), 323-352. https://doi.org/10.1007/s40692-015-0037-y

Supurwoko, Cari, Sarwanto, Sukarmin, Fauzi, Ahmad, \& Faradilla, L. (2017). Using computer simulation to improve high order thinking skills of physics teacher candidate students in Compton effect. Journal of Physics: Conference Series, 909, 012062. https://doi.org/10.1088/1742-6596/909/1/012062

Syaifulloh, R. B., \& Jatmiko, B. (2014). Penerapan pembelajaran dengan model guided discovery dengan lab virtual PhET untuk meningkatkan hasil belajar siswa kelas XI di SMAN 1 Tuban pada pokok bahasan teori kinetik gas. Jurnal Inovasi Pendidikan Fisika, 03(02), 174-179. 
Thiagarajan, S., Sammel, D. S., \& Melvyn, S. I. (1974). Instructional development for training teachers of exceptional children. Bloomington: Indiana University.

Tsai, C. C., \& Chou, C. (2002). Diagnosing students' alternative conceptions in science. Journal of Computer Assisted Learning, 18(2), 157-165. https://doi.org/10.1046/j.02664909.2002.00223.x

Wartono, W., \& Batlolona, J. R. (2018). Influence of discovery learning-based empirical-theoretical study assisted by animation PhET on the physics problem-solving in high school. Advanced in Social Science, Education and Humanities Research, 164, $47-51$.

Wulandari, F. R. A., Dewi, N. R., \& Akhlis, I. (2013). Pengembangan CD interaktif pembelaaran IPA terpadu tema energi dalam kehidupan untuk siswa SMP. Unnes Science Education Journal, 2(2), 262-268. https://doi.org/10.15294/usej.v2i2.2033 